\title{
Wet Season Trials on Growth and Yield of Six Newly Developed Chili Pepper Hybrids at Three Different Locations
}

\author{
Catur Herison ${ }^{\#}$, Merakati Handajaningsih ${ }^{\#}$, Fahrurrozi ${ }^{\#}$ and Rustikawati ${ }^{\#}$ \\ ${ }^{\#}$ Faculty of Agriculture, University of Bengkulu, Bengkulu 38371A, Indonesia \\ E-mail: catur_herison@unib.ac.id
}

\begin{abstract}
Chili pepper is one highest economic value vegetable crops in Indonesia. The wet season may adversely influence chili pepper yield in the field due to a high incidence of flower and fruit drop, and it may be more severe when it is combined with high temperature. The objective of this study might be to evaluate growth and yield of six newly developed chili pepper hybrids at three different agro climates during the wet season. The study was conducted in three locations differed mainly by elevation and soil type. They were low elevation (15 m above sea level - asl) with Ultisol, medium elevation (600 $\mathrm{m}$ asl) with Inceptisol, and high elevation $(1000 \mathrm{~m}$ asl) with andosol, during the peak of rainy season, November 2014 to March 2015 . In all location, the experiment was arranged in a randomized complete block design with three replications. The hybrid genotypes evaluated were H14, H17, H20, H23, $\mathrm{H39}$ and H5, and one commercial hybrid as a check, Dimas. The result showed that at low elevation, the hybrid genotype of H39 showed higher stem diameter, plant fresh and dry weight, the number of fruit and total fruit weight per plant. At medium altitude, H39 showed relatively higher plant height, stem diameter, plant dry-weight and total fruit number per plant than other hybrids did. However, total fruit weight per plant of Dimas and $\mathrm{H} 20$ were higher than that of other hybrids. At high elevation, plant height of H23, Dimas, or $\mathrm{H39}$ was relatively superior to that of other hybrids. In term of plant fresh and dry weight, $\mathrm{H20}, \mathrm{H} 23$, or $\mathrm{H17}$ was superior to other hybrids. However, H20, H17, or $\mathrm{H5}$ showed higher yield than other hybrids did. It seems that H39, Dimas, and H20 were more suitable at low, medium and high elevation, respectively, compared to other hybrids. Growth and yield of chili pepper grown at low elevation were lower than at medium or high altitude. The plant at high elevation produced yield higher than they did at medium altitude.
\end{abstract}

Keywords—capsicum annuum; growth; yield; hybrid; wet season.

\section{INTRODUCTION}

Chili pepper is the highest economic value vegetable in Indonesia. The high demand and seasonal production lead to its price fluctuate tremendously, ranging from IDR 10.000 to 100.000 per $\mathrm{kg}$ [1]. With the average consumption of chili pepper product of $3.12 \mathrm{~kg} / \mathrm{capita} / \mathrm{year}$ and with the population of Indonesia closed to 255.5 million in the year of 2015 [2], it pictured the high amount of chili pepper demand, either in the form of fresh or processed fruits. Moreover, it tends to increase yearly in harmony with the growth of population.

This high demand has not been entirely fulfilled by the national production indicated by a significant amount of chili pepper import which was as high as 12.000 ton/year [3] although its national productivity and harvesting area have increased significantly [2]. To mitigate further growing demand, therefore, there is a need to have more high yielding cultivars to elevate national chili pepper production with available planting areas.
Stable yield and other agronomic performances of new cultivars are substantial in the development of new high yielding varieties. The appearance of plants depends on the genotype, environmental conditions, and interaction between genotype and environment. A significant effect of genotype $x$ environmental interaction would directly impede the contribution of genetic components to the final performance of plants, thus hinder the selection of superior cultivars. The genotype $\mathrm{x}$ environment (GE) interaction complicates the selection to improve yield [4]. The presence of GE interaction reduces heritability and complicates the selection of superior genotypes with stable performance across environments [5]. This suggests that cultivar development should be directed toward obtaining cultivars that can adapt to wide range of environmental conditions or a specific environment.

Adaptability and stability analysis are essential to identify varieties with predictable performance or ones which are responsive to environmental variations in either specific or variable condition. These studies support a positive 
recommendation in cultivar selection. Adaptability refers to the ability of genotypes to take advantage of the existing environmental conditions, whereas stability relates to the capacity of a genotype response in a highly predictable manner to varied environmental conditions [6]. Consequently, for assessing a genotypic value and cultivar's stability for yield and agronomical performance, multi environmental trial data are required [7]. The objective of this study might be to evaluate growth and yield of six new chili pepper hybrids at three different locations during the rainy season.

\section{MATERIALS AND METHOD}

Six newly developed chili pepper hybrids, namely H5, $\mathrm{H} 14, \mathrm{H} 17, \mathrm{H} 20, \mathrm{H} 23$ and $\mathrm{H} 39$, and one commercially released cultivar, 'Dimas', were evaluated during the rainy season in the year of 2015 at three locations in different altitudes, i.e. Kandang Limun village of Muara Bangkahulu district (low altitude), Padang Lekat village of Kepahiyang district (medium altitude), and Air Duku village of Selupu Rejang district (high altitude), all of which were in Bengkulu Province of Indonesia. The locations differed in altitude, soil type, temperature, rainfall received per month from December 2014 to April 2015 (Table 1). At each site, the experiment was arranged in a randomized complete block design (RCBD) with three replications. The experimental units were plots of $1 \mathrm{~m}$ wide and $10 \mathrm{~m}$ long, consisting of 50 plants, set in two rows $50 \mathrm{~cm}$ apart.

TABLE I

THE CHARACTERISTICS OF TRIAL LOCATIONS

\begin{tabular}{|c|l|c|c|c|c|}
\hline $\begin{array}{c}\text { Locat } \\
\text { ion }\end{array}$ & \multicolumn{1}{|c|}{ Name } & $\begin{array}{c}\text { Altitude } \\
(\mathbf{m})\end{array}$ & $\begin{array}{c}\text { Soil } \\
\text { Type }\end{array}$ & $\begin{array}{c}\text { Tempe } \\
\text { rature } \\
\left({ }^{\mathbf{0}} \mathbf{C}\right)\end{array}$ & $\begin{array}{c}\text { Rainfall } \\
(\mathbf{m m} / \\
\mathbf{m o n t h})\end{array}$ \\
\hline 1 & $\begin{array}{l}\text { Muara } \\
\text { Bangkahulu }\end{array}$ & 15 & ultisol & 28.3 & 189.8 \\
\hline 2 & Kepahiyang & 600 & inceptisol & 25.4 & 288.5 \\
\hline 3 & Selupu Rejang & 1050 & andosol & 23.6 & 293.7 \\
\hline
\end{tabular}

Chili pepper seeds were germinated in wet tissue papers for five days. The young sprouts were then sowed in 72cell plastic trays containing seedling mix media of top soil and cow manure, in a ratio of 1:1 (v/v). The seedlings were grown in the greenhouse at Faculty of Agriculture, University of Bengkulu, at the tropical natural condition, for five weeks. The seedlings were watered twice a day and fertilized with $1000 \mathrm{ppm}$ of dissolved complex fertilizer of NPK 15-15-15 every other week. They were preventively protected from pest and diseases by spraying a mix solution of insecticide containing profenofos and fungicide containing mancozeb, in a concentration of $1.5 \mathrm{ml} / \mathrm{L}$ and 1.5 $\mathrm{g} / \mathrm{L}$, respectively.

In each location, the land was prepared in standard land preparation for commercially grown chili pepper. The land was manually tilled twice by hoe to have loose soil structure and then was formed to soil beds of $1 \mathrm{~m} \mathrm{x} 10 \mathrm{~m}$ with the height of $20 \mathrm{~cm}$ and $50 \mathrm{~cm}$ apart between the beds. Cow manure, urea, SP36, and $\mathrm{KCl}$ in the dose of 20,000, 200, 300 , and $150 \mathrm{~kg} / \mathrm{ha}$, respectively, were broadcasted over the beds and were mixed with the top soil of the beds. The beds were then covered with silver-black plastic mulch. The mulches were perforated by a fire loaded spherical can, $8 \mathrm{~cm}$ in diameters, with the distance of $50 \mathrm{~cm} \mathrm{x} 40 \mathrm{~cm}$, following the range commonly used by chili pepper farmer at West Sumatera [8]. The planting holes were made in the center of the mulch perforations, $6 \mathrm{~cm}$ in diameter and $10 \mathrm{~cm}$ deep, by a sharp end wood stalk.

Five-week old seedlings were transplanted into the planting holes to form the population of 50 plants per bed. Granular carbofuran containing insecticide at the rate of 20 $\mathrm{kg} / \mathrm{ha}$ was applied into the planting holes. The root ball of the seedlings was placed in the center of the holes, covered with top soil, and pressed firmly by hand. Watering was applied directly after transplanting.

Plant maintenance was done in a standard manner, involving replanting, watering, fertilizing, stalking and removing nonproductive branches. The plants which did not survive from transplanting operation were replanted with stock seedlings at two weeks after transplanting. The plants were watered when there was no rain for at least two days. Four weeks after transplanting, a rate of $200 \mathrm{~kg} / \mathrm{ha}$ urea was applied encircling the stem. Each plant stem was supported with a $75 \mathrm{~cm}$ bamboo stalk and was bound to the trunk. Non-reproductive branches below the first dichotomous branch were removed periodically to obtain vigorous plant growth. Pest and disease control was preventively done every week with the application of a combination of profenofos containing insecticide and mancozeb containing fungicide at the concentration of $2 \mathrm{~mL}$ and $2 \mathrm{~g} / \mathrm{L}$, respectively. Harvesting was done on ripening fruits, ones which have at least $75 \%$ of the fruit body turn red color, twice a week until all fruit developed in the first flowering period were harvested.

Data were collected on plant height, the diameter of the stem, plant fresh-weight, plant dry-weight, total number of fruits, fruit length, and fruit weight per plant. Analysis of variance (ANOVA) was performed on each location, and Duncan's Multiple Range Test (DMRT) at $\alpha=5 \%$ was used to separate the means in each location.

\section{RESULTS AND DISCUSSION}

The experiments were very well conducted. The transplanting operation run perfectly which resulted in close to $100 \%$ plant stand in all locations. Relatively high rainfall supports a healthy vegetative growth of the plant, and additional watering was not needed. However, high humidity also perfectly supports disease development. Preventive pest and disease control with a combination of insecticides, fungicides, and surfactants every week, fortunately, could minimize yield loss.

\section{A. Analysis of variance.}

Combined analysis of variance of seven chili pepper genotypes evaluated in three locations indicated that effect of genotypes, locations, or genotype $\mathrm{x}$ location interaction varied among observed variable. Effect of the site was highly significant on all variables, indicating that the trial sites diverged agro-ecologically. Except for plant freshweight and fruit weight per plant, the genotype factor significantly affected on growth and yield components. Those results indicated that there were differences among hybrids evaluated within one location or among locations. 
TABLE II

F VALUES OF THE COMBINED ANALYSIS OF VARIANCE ON ALL VARIABLES OBSERVED OF SEVEN CHILI PEPPER HYBRID GENOTYPES EVALUATED IN THREE DIFFERENT LOCATIONS

\begin{tabular}{|l|c|c|c|c|c|c|c|}
\hline Source of variation & $\begin{array}{c}\text { Plant } \\
\text { Height }\end{array}$ & $\begin{array}{c}\text { Stem } \\
\text { Diameter }\end{array}$ & $\begin{array}{c}\text { Plant Fresh } \\
\text { Weight }\end{array}$ & $\begin{array}{c}\text { Plant Dry } \\
\text { Weight }\end{array}$ & $\begin{array}{c}\text { Number of } \\
\text { Fruit }\end{array}$ & $\begin{array}{c}\text { Fruit Length } \\
\text { Fruit Weight } \\
\text { per Plant }\end{array}$ \\
\hline Location & $204.81^{* *}$ & $51.12^{* *}$ & $13.45^{* *}$ & $14.05^{* *}$ & $118.72^{* *}$ & $119.79^{* *}$ & $95.88^{* *}$ \\
\hline Rep(Location) & $4.35^{* *}$ & $15.57^{* *}$ & $3.79^{* *}$ & $3.51^{* *}$ & $6.02^{* *}$ & $0.51^{\mathrm{ns}}$ & $3.85^{* *}$ \\
\hline Genotype & $4.12^{* *}$ & $3.73^{* *}$ & $2.16^{\mathrm{ns}}$ & $7.56^{* *}$ & $6.15^{* *}$ & $7.64^{* *}$ & $1.69^{\mathrm{ns}}$ \\
\hline Genotype x Location & $3.23^{* *}$ & $1.05^{\mathrm{ns}}$ & $1.11^{\mathrm{ns}}$ & $3.13^{* *}$ & $2.26^{*}$ & $3.52^{* *}$ & $1.93^{\mathrm{ns}}$ \\
\hline CV $(\%)$ & $7.25^{*}$ & $6.67^{*}$ & $29.93^{*}$ & $24.93^{*}$ & $12.72^{2}$ & $7.22^{2}$ & $20.73^{2}$ \\
\hline
\end{tabular}

The genotype $\mathrm{x}$ location interaction had the significant effect on plant height, plant dry-weight, number of fruit, or fruit length (Table 2). For all those variables, the genotypes performed differently in different locations. Conversely, on other variables, the genotypic variation pattern was not affected by the environment. It was also noticed that difference due to the site was higher than that due to genotype, or genotype $\mathrm{x}$ location interaction, referring to the mean square (MS) value represented by calculated $\mathrm{F}$ value. These result revealed that variation due to the site dominantly contributed to the total variation occurred.

\section{B. Location 1: Low Altitude}

Analysis of variance performed on the data of Location 1 showed that there was a significant difference among hybrid genotypes observed on vegetative growth, yield components and yield. Mean separation by Duncan's Multiple Range Test (DMRT) at $\square=0.05$ revealed that with respect to plant height, H23, with the height of $62 \mathrm{~cm}$, was the highest among that of hybrids evaluated although it was not significantly different from H14. The least plant height was recorded in H5. Hybrid H39 showed the strongest growth indicated by the largest stem diameter $(1.2 \mathrm{~cm})$, even though it was not significantly different from H14, H23, H17 or $\mathrm{H} 20$. The smallest stem diameter was found in H5 and Dimas. The plant fresh and dry weight varied considerably high among genotypes. Plant fresh and dry weight of H39 was the highest among hybrids, $132.8 \mathrm{~g}$, and $84.4 \mathrm{~g}$, respectively (Table 3 ).

These results suggested that, in low altitude, H39 had stronger vegetative growth than other hybrids. Even though it grew shorter than H23, H39 had higher canopy width and density which ended up with higher plant fresh and dry weight. The newly developed hybrids evaluated showed comparable vegetative growth to the check variety, Dimas.
We found that hybrid H39 also had the highest number of harvested fruit per plant, which was 117 fruits, and was significantly higher compared to other hybrids. The second rank was H14, not significantly different from H20, H17, H23 or Dimas. The least fruit number was observed on H5. With regard to fruit size, the fruit length was between $9.7 \mathrm{~cm}$ and $10.7 \mathrm{~cm}$. The longest fruit was observed on $\mathrm{H} 20$, although statistically was not significantly different from H17, Dimas, H39 or H14. The least fruit length was observed on H5 or H23 (Table 4). In term of yield per plant, H39 was the best amongst hybrids evaluated. Accumulated from the seven harvests, its yield from seven harvesting times was $476.4 \mathrm{~g} /$ plant. With plant population of 20,000 plant/ha, it was estimated about 8.5 ton/ha (Fig. 1). It was noticed that our newly developed hybrids H39 was better than the check variety, and other new hybrids were about similar to the check variety, Dimas.

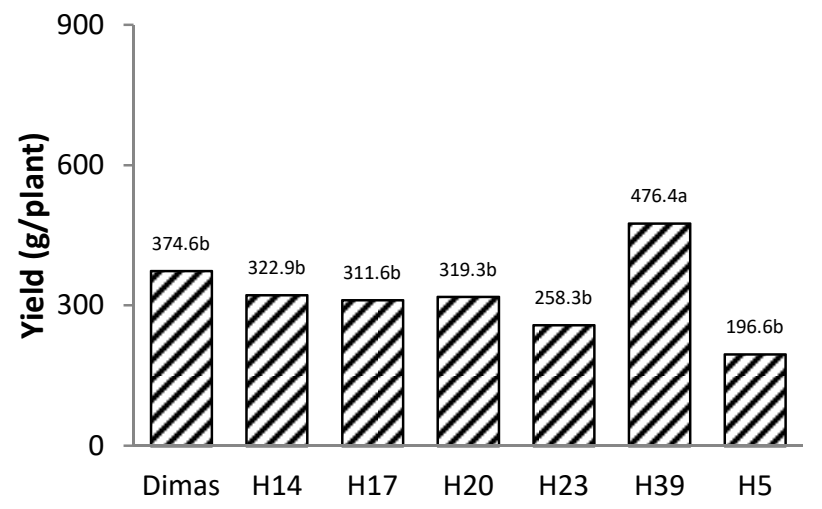

Fig. 1 Yield of hybrids evaluated in low altitude (15 m asl) of Kandang Limun village, district of Muara Bangkahulu, Bengkulu

TABLE III

GROWTH AND YIELD COMPONENTS OF SEVEN CHILI PEPPER HYBRIDS IN LOW ALTITUDE OF KANDANG LIMUN VILLAGE, DISTRICT OF MUARA BANGKAHULU, BENGKULU

\begin{tabular}{|l|c|c|c|c|c|c|}
\hline \multicolumn{1}{|c|}{ Genotype } & $\begin{array}{c}\text { Plant Height } \\
(\mathbf{c m})\end{array}$ & $\begin{array}{c}\text { Stem Diameter } \\
(\mathbf{c m})\end{array}$ & $\begin{array}{c}\text { Plant Fresh } \\
\text { Weight }(\mathbf{g})\end{array}$ & $\begin{array}{c}\text { Plant Dry } \\
\text { Weight (g) }\end{array}$ & $\begin{array}{c}\text { Total Number } \\
\text { of Fruit }\end{array}$ & $\begin{array}{c}\text { Fruit Length } \\
(\mathbf{c m})\end{array}$ \\
\hline Dimas & $52.6^{\mathrm{b}}$ & $1.01^{\mathrm{b}}$ & $56.1^{\mathrm{b}}$ & $32.3^{\mathrm{b}}$ & $81^{\mathrm{bc}}$ & $10.5^{\mathrm{ab}}$ \\
\hline H14 & $54.8^{\mathrm{ab}}$ & $1.11^{\mathrm{ab}}$ & $65.6^{\mathrm{b}}$ & $33.1^{\mathrm{b}}$ & $92^{\mathrm{b}}$ & $10.1^{\mathrm{ab}}$ \\
\hline H17 & $52.5^{\mathrm{b}}$ & $1.07^{\mathrm{ab}}$ & $67.2^{\mathrm{b}}$ & $33.0^{\mathrm{b}}$ & $81^{\mathrm{bc}}$ & $10.5^{\mathrm{ab}}$ \\
\hline H20 & $53.4^{\mathrm{b}}$ & $1.05^{\mathrm{ab}}$ & $61.4^{\mathrm{b}}$ & $37.4^{\mathrm{b}}$ & $87^{\mathrm{bc}}$ & $10.7^{\mathrm{a}}$ \\
\hline H23 & $62.0^{\mathrm{a}}$ & $1.11^{\mathrm{ab}}$ & $84.1^{\mathrm{b}}$ & $47.5^{\mathrm{b}}$ & $81^{\mathrm{bc}}$ & $9.7^{\mathrm{b}}$ \\
\hline H39 & $52.0^{\mathrm{b}}$ & $1.20^{\mathrm{a}}$ & $132.8^{\mathrm{a}}$ & $84.4^{\mathrm{a}}$ & $117^{\mathrm{a}}$ & $10.4^{\mathrm{ab}}$ \\
\hline H5 & $46.3^{\mathrm{b}}$ & $0.98^{\mathrm{b}}$ & $67.4^{\mathrm{b}}$ & $31.5^{\mathrm{b}}$ & $7^{\mathrm{b}}$ & $9.7^{\mathrm{b}}$ \\
\hline
\end{tabular}


TABLE IV

GROWTH AND YIELD COMPONENTS OF SEVEN CHILI PEPPER HYBRIDS IN MEDIUM ALTITUDE OF PADANG LEKAT VILLAGE, DISTRICT OF KEPAHIYANG, KEPAHIYANG

\begin{tabular}{|l|c|c|c|c|c|c|}
\hline \multicolumn{1}{|c|}{ Genotype } & $\begin{array}{c}\text { Plant Height } \\
(\mathbf{c m})\end{array}$ & $\begin{array}{c}\text { Stem Diameter } \\
(\mathbf{c m})\end{array}$ & $\begin{array}{c}\text { Plant Fresh } \\
\text { Weight }(\mathbf{g})\end{array}$ & $\begin{array}{c}\text { Plant Dry } \\
\text { Weight }(\mathbf{g})\end{array}$ & $\begin{array}{c}\text { Total Number } \\
\text { of Fruit }\end{array}$ & $\begin{array}{c}\text { Fruit Length } \\
(\mathbf{c m})\end{array}$ \\
\hline Dimas & $83.3^{\mathrm{b}}$ & $1.27^{\mathrm{ab}}$ & $141.4^{\mathrm{a}}$ & $51.6^{\mathrm{ab}}$ & $108^{\mathrm{b}}$ & $15.0^{\mathrm{abc}}$ \\
\hline H14 & $76.1^{\mathrm{b}}$ & $1.21^{\mathrm{b}}$ & $89.1^{\mathrm{a}}$ & $42.3^{\mathrm{b}}$ & $83^{\mathrm{bc}}$ & $14.4^{\mathrm{bc}}$ \\
\hline H17 & $76.8^{\mathrm{b}}$ & $1.34^{\mathrm{ab}}$ & $115.9^{\mathrm{a}}$ & $49.3^{\mathrm{ab}}$ & $94^{\mathrm{bc}}$ & $13.2^{\mathrm{d}}$ \\
\hline H20 & $82.0^{\mathrm{b}}$ & $1.30^{\mathrm{ab}}$ & $136.2^{\mathrm{a}}$ & $64.6^{\mathrm{a}}$ & $90^{\mathrm{bc}}$ & $15.8^{\mathrm{a}}$ \\
\hline H23 & $80.9^{\mathrm{b}}$ & $1.30^{\mathrm{ab}}$ & $114.4^{\mathrm{a}}$ & $51.7^{\mathrm{ab}}$ & $96^{\mathrm{bc}}$ & $15.2^{\mathrm{ab}}$ \\
\hline H39 & $100.0^{\mathrm{a}}$ & $1.44^{\mathrm{a}}$ & $137.2^{\mathrm{a}}$ & $50.1^{\mathrm{ab}}$ & $143^{\mathrm{a}}$ & $13.3^{\mathrm{d}}$ \\
\hline H5 & $83.5^{\mathrm{b}}$ & $1.29^{\mathrm{ab}}$ & $129.6^{\mathrm{a}}$ & $44.3^{\mathrm{ab}}$ & $77^{\mathrm{b}}$ & $13.9^{\mathrm{cd}}$ \\
\hline
\end{tabular}

\section{Location 2: Medium Altitude}

Analysis of variance on data of Location 2 indicated that there was no significant difference among genotypes observed on vegetative growth, but plant height, and fruit diameter. Mean comparison with DMRT at $\alpha=0.05$ on plant height showed that hybrid H39 was the highest among hybrids tested. Its height was $100 \mathrm{~cm}$. On the other hand, hybrid H14 was the lowest one, although it was not significantly different from other hybrids. In term of stem diameter, the variation among genotype was considered small. The highest stem diameter was observed on H39 which was 1.44 , and the lowest was recorded on H14 which was $1.21 \mathrm{~cm}$ (Table 4). It was noticeable that about these two variables, the newly developed hybrids were of comparable to the commercial variety, Dimas.

There was no significant variation on plant fresh-weight among hybrids. They showed almost similar values. However, variation among hybrids was observed on plant dry-weight. The highest plant dry weight was found on H20 $(64.6 \mathrm{~g})$, and the lowest one was on H14 (Table 4). However, similar to other growth variables, previously mentioned, either plant fresh or dry weight of new hybrids was comparable to the check variety.

With respect to a total number of fruits per plant, genotype H39 showed the highest number of fruits, which were 147 fruits per plant, among hybrids including the check variety Dimas. The second highest fruit number was recorded in Dimas, but it did not differ from that of other hybrids, except H5. With regard to fruit length, H20 produced the longest fruits, $15.8 \mathrm{~cm}$, followed by $\mathrm{H} 23$ and Dimas, $15.2 \mathrm{~cm}$ and $15 \mathrm{~cm}$, respectively. Hybrid bearing shortest fruit length among hybrids evaluated was H17 (Table 4). Most our new hybrids showed equal fruit length to the commercial check variety, Dimas.
With regard to the yield per plant, there was relatively high variation among hybrids, in a range between 453.9 $\mathrm{g} /$ plant (9.8 ton/ha) and $707.4 \mathrm{~g} / \mathrm{plant}$ (14.1 ton/ha). Dimas, the check variety, produced the highest fruit weight, which was $707.4 \mathrm{~g} /$ plant (14.1 ton/ha), among hybrids. However, it did not significantly differ from $\mathrm{H} 20$ and $\mathrm{H} 23$, which produced $611.1 \mathrm{~g} / \mathrm{plant}$ (12.2 ton/ha) and $576.0 \mathrm{~g} /$ plant (11.5 to/ha) (Fig. 2).

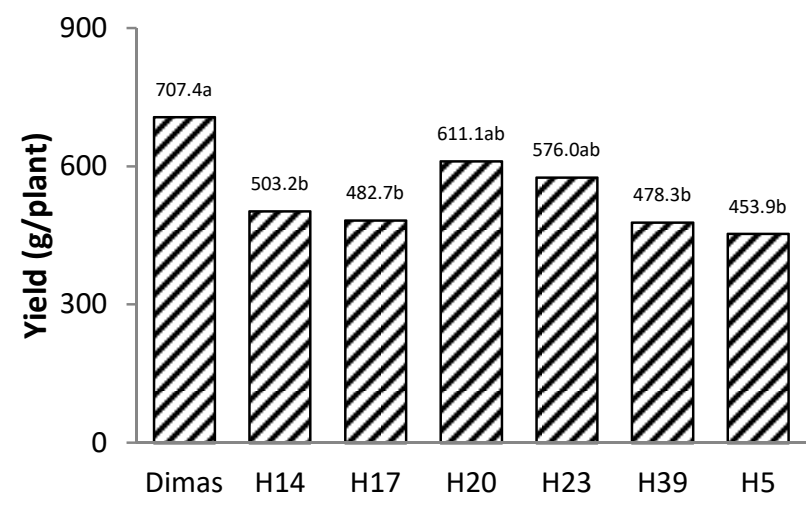

Fig. 2 Yield of hybrids evaluated in medium altitude (600 m asl) of Padang Lekat village, district of Kepahiyang, Kepahiyang

\section{Location 3: High Altitude}

Analysis of variance on data collected from experiment Location 3 revealed that there was significantly different among hybrids in all growth and yield variable observed, except stem diameter, the total number of fruit and fruit weight per plant. Mean comparison with DMRT at $\alpha=0.05$ showed that Hybrid H23 and Dimas had the highest plant height which was $84.25 \mathrm{~cm}$ and $83.64 \mathrm{~cm}$, respectively, although they did not significantly differ from H39, H17 or H5.

TABLE V

GROWTH AND YIELD COMPONENTS OF SEVEN CHILI PEPPER HYBRIDS IN HIGH ALTITUDE OF AIR DUKU VILLAGE, DISTRICT OF SELUPU REJANG, REJANG LEBONG

\begin{tabular}{|l|l|c|c|c|c|c|}
\hline \multicolumn{1}{|c|}{ Genotype } & $\begin{array}{c}\text { Plant Height } \\
(\mathbf{c m})\end{array}$ & $\begin{array}{c}\text { Stem } \\
\text { Diameter (cm) }\end{array}$ & $\begin{array}{c}\text { Plant Fresh } \\
\text { Weight (g) }\end{array}$ & $\begin{array}{c}\text { Plant Dry } \\
\text { Weight (g) }\end{array}$ & $\begin{array}{c}\text { Total Number } \\
\text { of Fruit }\end{array}$ & $\begin{array}{c}\text { Fruit Length } \\
(\mathbf{c m})\end{array}$ \\
\hline Dimas & $83.64^{\mathrm{a}}$ & $1.11^{\mathrm{a}}$ & $87.3^{\mathrm{abc}}$ & $51.5^{\mathrm{bcd}}$ & $108^{\mathrm{a}}$ & $14.7^{\mathrm{ab}}$ \\
\hline H14 & $76.01^{\mathrm{b}}$ & $1.07^{\mathrm{a}}$ & $73.1^{\mathrm{c}}$ & $37.9^{\mathrm{d}}$ & $95^{\mathrm{a}}$ & $13.6^{\mathrm{abc}}$ \\
\hline H17 & $79.13^{\mathrm{ab}}$ & $1.16^{\mathrm{a}}$ & $109.6^{\mathrm{ab}}$ & $74.4^{\mathrm{abc}}$ & $120^{\mathrm{a}}$ & $11.0^{\mathrm{c}}$ \\
\hline H20 & $76.10^{\mathrm{b}}$ & $1.17^{\mathrm{a}}$ & $108.3^{\mathrm{ab}}$ & $87.8^{\mathrm{a}}$ & $105^{\mathrm{a}}$ & $13.7^{\mathrm{abc}}$ \\
\hline H23 & $84.25^{\mathrm{a}}$ & $1.13^{\mathrm{a}}$ & $111.4^{\mathrm{a}}$ & $79.1^{\mathrm{ab}}$ & $106^{\mathrm{a}}$ & $16.2^{\mathrm{a}}$ \\
\hline H39 & $81.79^{\mathrm{ab}}$ & $1.15^{\mathrm{a}}$ & $102.5^{\mathrm{ab}}$ & $72.2^{\mathrm{abc}}$ & $107^{\mathrm{a}}$ & $12.0^{\mathrm{bc}}$ \\
\hline H5 & $78.05^{\mathrm{ab}}$ & $1.08^{\mathrm{a}}$ & $81.1^{\mathrm{bc}}$ & $44.3^{\mathrm{cd}}$ & $104^{\mathrm{a}}$ & $12.8^{\mathrm{bc}}$ \\
\hline
\end{tabular}


In term of stem diameter, there was not significantly different observed among hybrids. With regard to plant fresh-weight, hybrid $\mathrm{H} 23$ was the highest one, which was $111.4 \mathrm{~g}$. The second rank was H39, followed by H17 and H20. The lowest hybrid was H14. Concerning plant dry weight, hybrid H20 was the highest among hybrids, which was $87.8 \mathrm{~g}$, although it was not significantly different from H23, H17, and H39 (Table 5). The lowest plant dry weight was recorded in H14. These result indicated that hybrid $\mathrm{H} 20, \mathrm{H} 23$, and $\mathrm{H} 17$ revealed more vigorous vegetative growth than other hybrids. These results demonstrated that, at high altitude, all our new hybrids, except H5 and H14, were comparable to the released check variety, Dimas, in vegetative growth performance.

No apparent differences were observed for the number of fruit among hybrids. They bore fruits almost similarly in a range between 95 and 120 fruits. However, with regard to fruit length, they were significantly divergence. Hybrid H23 produced the longest fruits, which was $16.2 \mathrm{~cm}$, followed by Dimas, H20, or H14. Hybrid H17 bore fruits having the shortest fruit length among hybrids (Table 5). No statistically differences among hybrids in term of fruit yield per plant, which was in a range between $710.7 \mathrm{~g} /$ plant $(14.2$ ton/ha) and $810.1 \mathrm{~g} /$ plant (16.2 ton/ha). However, H20 tended to have higher yield compared to other hybrids (Fig. 3 ). The second highest yield was H17. The yield data highly confirmed that, at high altitude, the newly developed hybrids were comparable to the commercial check variety, Dimas, even hybrid H20 was slightly better.

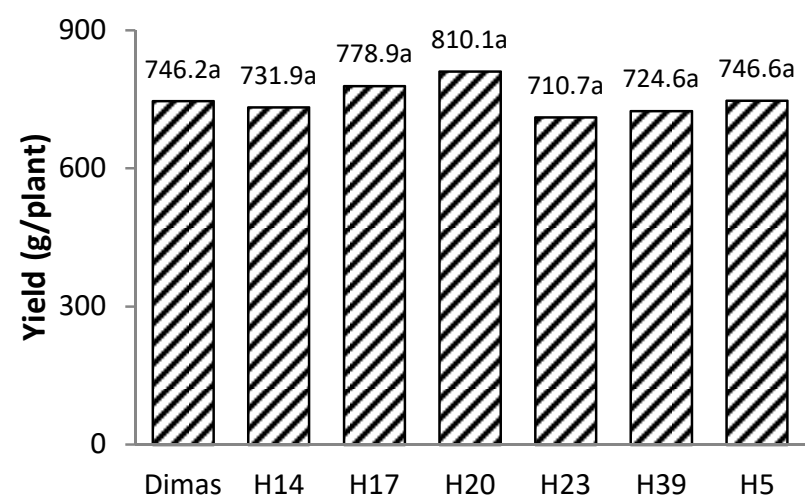

Fig. 3 Yield of hybrids evaluated in medium altitude (1100 m asl) of Air Duku village, district of Selupu Rejang, Rejang Lebong

Comparing three different locations, chili pepper plants grown in high or medium altitude tended to grow taller than that in low altitude. Plant height of the plants grown in medium altitude was slightly taller than that at high altitude. Almost similar to the plant height, stem diameter of plants grown in medium altitude was bigger than that of another altitude, and the smallest stem diameter was observed on the plants in low altitude. A similar trend was detected on plant fresh-weight. However, dry-weight of plants grown in high altitude was higher than that of in medium altitude. The lowest one was the plants grown in low altitude (Table 6). Those data indicated that the higher the altitude, the more vigorous the growth of plants.
From the average data, it was also noticeable that the higher the altitude, the greater total number of fruits of the plant. The plants grown in high altitude produced a higher total number of harvested fruit than that in medium or low altitude. Similarly, the plant grown in medium altitude produced the total number of fruit more than they did at low altitude. The plants cultivated in moderate or high altitude produced significantly longer fruit than that in low altitude. Although the plants in medium altitude produced slightly longer fruits than that in high altitude, they were not significantly different (Table 6). With regard to yield, the plant grown in higher altitude produced a higher yield. The average yield of the plant in high altitude was about 749.9 $\mathrm{g} /$ plant (14.98 ton/ha), followed by that of in medium altitude, $544.5 \mathrm{~g} / \mathrm{plant}$ (10.89 ton/ha). And the lowest one was the plant grown in low altitude (Fig.4). From the above finding, it seems that high altitude was more favorable for chili pepper production.

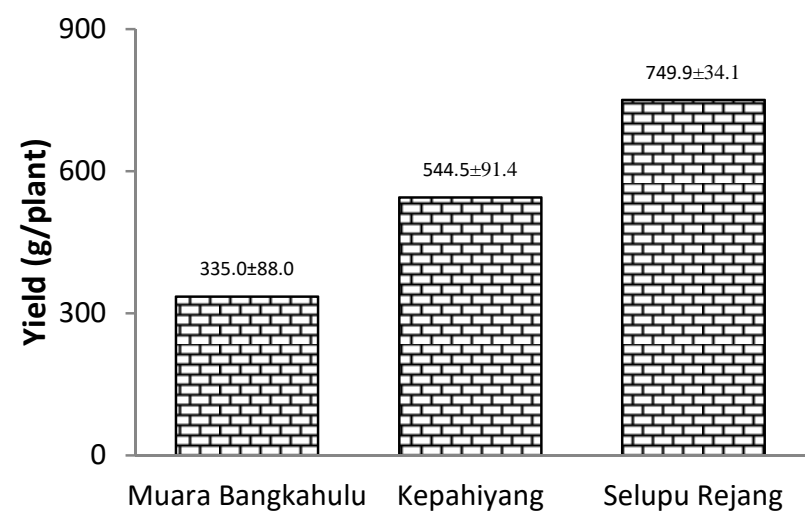

Fig. 4 Average yield of hybrids evaluated in three different location

\section{E. Discussion.}

Multi location trial was conducted mainly to identify cross over or non-cross over type of genetic $\mathrm{x}$ environment interaction [9]. The former refers to the change in ranking performance of genotype on different environments. Although this phenomenon makes breeders difficult to justify the superior variety, it is useful to identify specific location genotypes. The later indicates the stability performance of genotype over a series of divergent environments, which is valuable to determine stable genotypes.

An ideal multi location trial requires a set of divergent environments. The combined analysis of variance in this study revealed that effect of location was highly significant difference and predominantly contributed the total variation. Highly significant difference of the effect of location over the effect of genetic or genetic $x$ location interaction indicated the existence of difference in mega environment [10]. Therefore, locations chosen in this study were highly representative for a diverse mega environment suitable for multi locations trial. The difference of location affected the growth and yield of chili pepper hybrids evaluated, represented by plant height, stem diameter, plant fresh and dry weight, number of fruits, fruit length and yield per plant. 
TABLE VI

AVERAGE GROWTH AND YIELD COMPONENTS OF SEVEN CHILI PEPPER HYBRIDS IN THREE DIFFERENT LOCATIONS

\begin{tabular}{|l|c|c|c|c|c|c|}
\hline Location & $\begin{array}{c}\text { Plant Height } \\
(\mathbf{c m})\end{array}$ & $\begin{array}{c}\text { Stem Diameter } \\
(\mathbf{c m})\end{array}$ & $\begin{array}{c}\text { Plant Fresh } \\
\text { Weight }(\mathbf{g})\end{array}$ & $\begin{array}{c}\text { Plant Dry } \\
\text { Weight (g) }\end{array}$ & $\begin{array}{c}\text { Total Number } \\
\text { of Fruit }\end{array}$ & $\begin{array}{c}\text { Fruit Length } \\
(\mathbf{c m})\end{array}$ \\
\hline $\begin{array}{l}\text { Muara } \\
\text { Bangkahulu }\end{array}$ & $53.4 \pm 4.64$ & $1.08 \pm 0.07$ & $76.4 \pm 26.35$ & $42.8 \pm 19.21$ & $88.1 \pm 13.96$ & $10.2 \pm 0.38$ \\
\hline Kepahiyang & $83.2 \pm 7.96$ & $1.31 \pm 0.07$ & $123.4 \pm 18.38$ & $50.5 \pm 7.18$ & $98.8 \pm 21.83$ & $14.4 \pm 1.00$ \\
\hline Selupu Rejang & $79.9 \pm 3.42$ & $1.12 \pm 0.04$ & $96.2 \pm 15.49$ & $63.9 \pm 19.13$ & $106.5 \pm 7.20$ & $13.4 \pm 1.72$ \\
\hline
\end{tabular}

Plant height is the most measurable vegetative growth of many plants, including chili pepper. In this study, there was high variation amongst genotypes or locations. Those results indicated that plant height was subjected to be influenced by either genotypes or environmental factors. Based on the mean data, plant height seemed to correlate to stem diameter. Almost in all locations, increase in plant height often accompanied by the increase in stem diameter which could minimize lodging. Nevertheless, increase in plant height did not entirely coincide with the increase in plant fresh and dry weight. Plant weight was a typical feature of total biomass accumulated during the growing period. There might be many other factors contribute to the plant fresh and dry weight to be considered, such as canopy width and density, number of branches, number of leaves etc. These variables might be of future investigation.

A total number of fruits was counted from the fruit of the first flowering period which could be harvested up to 10 or more times. When all of the fruits are harvested, chili pepper plant usually starts the second flowering period. Not all of the flowers will form harvested size fruit. The total number of fruits is determined by fruit bearing capacity of the plant in normal and healthy condition. In the field, there were many factors which contributed to the failure of flowers to form marketable fruits, such as insects, diseases, temperature, rainfall, humidity, and climatic conditions etc. Consequently, the total number of fruits was less than the potential fruit formation of genotypes. The results of this study also indicated that higher altitude was more favorable for fruit formation of genotypes evaluated. However, genotypes grown in medium altitude produce higher mean fruit length compared to that of higher or lower altitude.

Fruit weight per plant is a resultant of number fruits and weight per fruit. In this study, similar to the number of fruits, higher altitude was favorable for higher fruit weight. This result was not in agreement with the finding of [11] that higher yield did not correlate to higher altitude. This different result might be attributed to different material genetic used in this research.

Fruit weight, however, was not highly coincidence with the total number of fruits. This might be due to the weight per fruit factor which was influenced by many aspects, such as seed weight, thickness of fruit flesh, and fruit water content.

The significant variation of plant height, stem diameter, plant fresh and dry weight, number of fruits, and fruit length of chili pepper hybrids studied might be attributed to genetic potential as well as environmental factors. Growth and yield performance patterns of genotypes were not similar among locations. The different location had different effect on the performance of genotypes tested. Those phenomena indicated that genotype $\mathrm{x}$ environment interaction existed in this study. The extent of this type of interaction was highly depended upon genotype and the complexity of environmental factors [12]. Different altitude of locations used in this study was responsible for enormous environment variation. Different altitudes bring about differences in air temperature, soil type, and rainfall. Slope and elevation affected soil evolution which contributed to variation in soil type, thickness of the soil profile and solum, clay, organic carbon and total nitrogen percentages and cation exchange capacity (CEC) [13].

The result of this study was in agreement with the results of [14] that agronomic and morphological characters of chili pepper lines varied either within or among agro-ecological zones. The former was due to inherited factors, and the latter was attributed to environmental variation and genetic $\mathrm{x}$ environment interaction. The result was also in harmony with [15] that growth and yield of genotypes tested varied among environment. The extent of variation and variation pattern of genotypes was not similar between locations indicating that there were both genetics and environment factors involved in the expression of measured variables. High variation of genotype performances was influenced by environment followed by genotype by environment interaction and the genetic factor [16]. This variation indicated that there was contrast among environments and the occurrence of differential response of the genotypes to environmental effects. The environment was the source of variation most contributed to the performance of genotypes, indicating that the edaphic and agro climatic features of each environment significantly interfered in the trait measured [17]. The interaction between genotype $\mathrm{x}$ environment factors indicated that the effects of all variations were not explained individually for characters under study, and the effect provided by the environment condition promoted differences in expression of these traits [18].

\section{CONCLUSION}

In low altitude, hybrid genotype H39 showed higher vegetative growth and yield than other hybrids. In medium altitude, H39 exhibited higher vegetative and reproductive growth. However, total fruit weight per plant of Dimas and H20 were higher than that of other hybrids. In high altitude, $\mathrm{H} 20, \mathrm{H} 23$, and $\mathrm{H} 17$ revealed vegetative growth superior to other hybrids. However, H20, H17, and H5 showed higher yield than other hybrids did. It seems that H39, Dimas, and H20 were more suitable at low, medium and high elevation, respectively, compared to other hybrids. Growth and yield of chili pepper grown at low elevation were lower than that of medium or high altitude. The plant grown at high 
elevation produced a higher yield than they did at medium altitude. Further evaluation is needed to access the yield stability.

\section{ACKNOWLEDGMENT}

The authors would like to thank the Directorate of Research and Social Services of the Ministry of Research, Technology and Higher Education of the Republic of Indonesia for funding support of this research. We would also thank students for collecting data and farmers for doing the field works.

\section{REFERENCES}

[1] D. Indarti, Outlook Cabai, Pusat Data dan Sistem Informasi Pertanian, Sekretariat Jenderal Kementerian Pertanian Republik Indonesia, ISSN:1907-1507, 2015.

[2] Subdirectorate of Statistical Promotion and Services, Trends of Selected Socio-Economic Indicators of Indonesia, November 2016, ISSN: 2085-5664, BPS-Statistics Indonesia, 2016

[3] Subdirectorate of Import Statistics, Foreign Trade Statistical Buletin. Import, BPS-Statistics Indonesia, ISSN:0126-3668, 2016.

[4] N. Sabaghnia, M. Mohammadi, R. Karimizadeh, "Interpreting genotype $\mathrm{x}$ environment interaction of bread wheat genotypes using different nonparametric stability statistics," Agriculture \& Forestry, vol. 59(2), pp. 21-35, 2013.

[5] Li L, Wegenast T, Li H, Dhillon BS, Longin CFH, Xu X, Melchinger $\mathrm{AE}$, Chen $\mathrm{S}$, "Estimation of quantitative genetic and stability parameters in maize under high and low N levels," Maydica, vol. 56 , pp. 25-34, 2011

[6] A. Santos, G. Ceccon, E. V. Rodrigues, P. E. Teodoro, P. A Makimo, V. B. Alves, J. F. Silva, A. M. Corrêa, R. C. F. Alvares and F. E. Torres, "Adaptability and stability of cowpea genotypes to Brazilian Midwest," Afr. J. Agric. Res., vol. 10(41), pp 3901-3908, 2015 .

[7] B. Dane, J. Mirjana, I. Sonja, A. Irfan,K. Mensur, "Evaluation of Balkan wheat cultivars for grain yield stability based on the GGE biplot analysis," Int. J. Agri. R, vol. 8(5), pp. 32-38, 2016
[8] D. Evaliza, N. E. Putri, and H. Fauza, "Lotanbar chili farming analysis in support of a new superior cultivar from the district of Limapuluh Kota”, Ijaseit vol.5(1), pp.40-43, 2015.

[9] Y. Meng, P. Ren, X. Ma, B. Li, Q. Bao, H. Zhang, J. Wang, J. Bai, and $\mathrm{H}$. Wang, "GGE biplot-based evaluation of yield performance of barley genotypes across different environments in China”, J. Agr. Sci. Tech. Vol. 18, pp. 533-543, 2016.

[10] K. Ukalski and M. Klisz, "Application of GGE biplot graphs in multi-environment trials on selection of forest trees" Folia Forestalia Polonica, Series A - Forestry, Vol. 58 (4), pp.228-239, 2016.

[11] M. Syukur, S. Sujiprihati, R. Yunianti, D. A. Kusumah, "Parametric stability analysis for yield of chili pepper (Capsicum annuum L.)", J. Agron. Indonesia, vol. 39(1), pp. 31-37, 2011.

[12] A. A. Mattjik, I. M. Sumertajaya, A.F. Hadi, and G. N. A. Wibawa, A dditive Main-effect and Multiplicative Interaction (AMMI) Modeling : present and future (in Indonesian), IPB Press, 2011.

[13] H. Rezaei, A. A. Jafarzadeh, A. Alijanpour, F. Shahbazi, K. V. Kamran, "Effect of slope position on soil properties and types along an elevation gradient of Arasbaran Forest, Iran", Ijaseit vol.5 (6), pp.449-456, 2015.

[14] G. O. Nkansah, A. Ayarna and T. J. Gbokie, "Morphological and yield evaluation of some capsicum pepper lines in two agroecological zone of Ghana," J.Agron, vol. 10(3), pp. 84-91, 2011.

[15] V. P. P. Rahadi, M. Syukur, S. Sujiprihati and R. Yunianti, "Nonparametric stability analysis of yield for nine chili pepper (Capsicum annuum L.) genotypes in eight environments," Agrivita, vol. 35, pp.193-200, 2013.

[16] S. Tariku and T. Lakew, "Performance of rain fed lowland rice genotypes in multi environment trials as analyzed using GGE biplot, RA J. Appl. Res. vol.2, pp. 392-403, 2016.

[17] A. M. Correa, M.C. Gonçalves, P.E. Teodoro, "Pattern analysis of multi-environment trials in common bean genotypes", Biosci. J., Uberlândia, vol. 32, pp. 328-336, Mar./Apr. 2016

[18] C. Busanello, V. Q. de Souza, A. C. de Oliveira, M. Nardino, D. Beretta, B. O. Caron, D. Schmidt, V. F. de Oliveira, V. A. Konflaz, "Adaptability and stability of corn hybrids in southern Brazilian environments", J. Agric. Sci., vol. 7(9), pp. 228-235, 2015 